\title{
Article
}

\section{Employee voice: An antecedent to organisational engagement?}

Ruck, Kevin, Welch, Mary and Menara, Barbara

Available at http://clok.uclan.ac.uk/17634/

Ruck, Kevin, Welch, Mary and Menara, Barbara (2017) Employee voice: An antecedent to organisational engagement? Public Relations Review . ISSN 0363-8111

It is advisable to refer to the publisher's version if you intend to cite from the work. http://dx.doi.org/10.1016/j.pubrev.2017.04.008

For more information about UCLan's research in this area go to

http://www.uclan.ac.uk/researchgroups/ and search for < name of research Group>.

For information about Research generally at UCLan please go to http://www.uclan.ac.uk/research/

All outputs in CLoK are protected by Intellectual Property Rights law, including Copyright law. Copyright, IPR and Moral Rights for the works on this site are retained by the individual authors and/or other copyright owners. Terms and conditions for use of this material are defined in the policies page.

\section{CLoK}

Central Lancashire online Knowledge www.clok.uclan.ac.uk 


\section{Pre-publication version of: \\ Employee voice: An antecedent to organisational engagement? \\ Dr Kevin Ruck, Dr Mary Welch, Dr Barbara Menara.}

Accepted for publication in:

Public Relations Review

It is advisable to refer to the publisher's version if you intend to cite from the work.

Authors:

Dr Kevin Ruck, Co-founder, PR Academy, Maidstone Studios, Maidstone, Vinters Park, Kent ME14 5NZ. Email: kevin.ruck@pracademy.co.uk Corresponding author

Dr Mary Welch, Associate Lecturer, Faculty of Business and Law, The Open University, Milton Keynes, MK7 6AA, UK. Email: mwelch2@uclan.ac.uk

Dr Barbara Menara, Lecturer in Human Resource Management, School of Management, University of Central Lancashire, Preston, Fylde Rd, Preston PR1 2HE. Email: BMenara@uclan.ac.uk 


\begin{abstract}
Employee engagement is recognised as important for organisational effectiveness and a factor in achieving innovation and competiveness. Despite the importance of engagement, relatively little research has yet been done on communication and engagement. This paper aims to contribute to knowledge in this area by providing insight on internal communication and organisational level employee engagement. The paper reports the results of a study exploring associations between aspects of internal communication and organisational engagement. Taking an employee-centric approach, the paper investigates employee satisfaction with opportunities to exercise their voice, and assesses employee views on the quality of senior management receptiveness to employee voice. The paper aims to address gaps in the literature by exploring potential associations between employee voice and organisational engagement.
\end{abstract}

A questionnaire was used to gather data from 2066 participants in five UK-based organisations. The questionnaire used in the study was designed to explore satisfaction with upward employee voice and senior management receptiveness. It also enables exploration of the relationship between upward employee voice, senior manager receptiveness and emotional organisational engagement. A significant and positive relationship was found between upward employee voice and emotional organisational engagement; and between senior manager receptiveness and emotional organisational engagement. Regression analysis suggests that the majority of the employee voice variables included in the study predict emotional organisational engagement. While the study involved data collected from a reasonably large number of participants, it was limited to five UKbased organisations.

The paper includes reflection on practical implications of the findings for internal communication management. In particular, it considers implications for senior management communication with employees including building employee voice into internal corporate communication strategies and plans. Suggestions for further research are included. The paper contributes to employee engagement literature by expanding insight on organisational engagement. Since relatively little previous research has considered the interplay between internal communication, organisational engagement and employee voice, the study makes a useful contribution to an under-researched area.

\title{
Keywords
}

Internal communication, upward employee voice, senior manager receptiveness, employee engagement, organisational engagement

\section{Highlights}

- The paper considers potential contributions of internal communication to employee engagement.

- Two aspects of employee voice are highlighted: upward employee voice; senior manager receptiveness

- The paper focusses on organisational employee engagement rather than job or work engagement.

- The empirical study investigates the interplay between employee voice and organisational employee engagement. 
- The findings suggest that paying attention to both sides of the employee voice coin is necessary to realise the potential of organisational employee engagement.

\section{Funding}

The work was supported by an Arnoux part-PhD studentship from the University of Central Lancashire, UK. 


\section{Introduction}

This paper considers associations between upward employee voice, senior manager receptiveness to voice and employee engagement. In doing so, the paper addresses a research gap identified by Gruman and Saks (2014, p. 459) who observe that 'relatively little attention has been given to the relationship between voice and engagement'. This paper addresses that gap in knowledge and investigates the associations between employee voice and organisational engagement through a survey involving five UK-based organisations.

Employee voice is already a well-established concern in human relations management literature (Marchington, 2015) which recognises the benefits organisations accrue from robust systems of employee involvement and participation. Satisfaction with employee voice, in terms of having sufficient opportunities for providing upward feedback, has been recognised as a driver of employee engagement (Truss, Soane, Edwards, Wisdom, Croll \& Burnett 2006; Ruck \& Welch 2012). However, the employee voice concept is as yet under-researched in public relations literature. This is surprising given the potential insights public relations and communication management practitioners and academics could offer to assist leaders to tap into employee views. This viewpoint broadens conceptions of the role of internal communicators as it goes beyond the notion that: 'An internal public relations practitioner can act as the organization's official voice to address internal publics in a cohesive, coordinated fashion; this basic rule of external public relations practice should be applied internally, as well.' (Seltzer, Gardner, Bichard \& Callison 2012 p. 135). As well as addressing internal publics, internal communicators can stimulate employee voice contributions. Furthermore, they can play a strategic role by conveying employee views to senior managers and facilitating leadership receptiveness.

As Rees, Alfes and Gatenby (2013) observe, employee voice was originally equated with trade union membership and collective bargaining, but it is now more frequently seen as a range of ways in which employees have a say about what goes on in their organisation. This is summarised as employees' 'speaking up' with constructive ideas that aim to improve or change the status quo. If employee voice is listened to and acted upon employees may respond with heightened engagement. Employee voice is therefore an aspect of internal communication that may positively affect employee engagement with the organisation. The paper begins with a review of literature on the key concepts for the study. The review sets out the research questions and hypotheses investigated in the research. Next, the methods used to investigate the research questions are outlined followed by analysis and discussion of the findings. Implications for practice, theory and future research are provided in the conclusion.

\section{Literature review}

Scholars and practitioners are interested in building employee engagement because of its perceived positive impact on organisational effectiveness. Physical employee engagement is manifest in employee actions, one form of which is employee communication behaviour involving the exercise of voice. This review sets out the conceptual framework for the study by considering the concepts of internal communication and dialogue, employee voice and employee silence. Then it goes on to discuss the concept of organisational engagement. A set of research questions and hypotheses are constructed along with a conceptual framework model. The paper 
extends work in this area by empirically exploring the employee communication-engagement relationship, specifically considering the role of employee voice.

\section{Internal communication and dialogue}

Communication is a key factor for organisational effectiveness (Hargie \& Tourish, 1993; Dickson, Rainey \& Hargie, 2003; Quinn \& Hargie, 2004; Downs \& Adrian, 2004; Robson \& Tourish, 2005; Verčič, Verčič \& Sriramesh, 2012) and occurs formally and informally at all workplace levels. An Internal Communication Matrix has been posited (Welch \& Jackson, 2007) to capture some of the complexity of communication inside organisations. The matrix distinguishes dimensions of internal communication relating to team peer, project group, line-manager and senior manager communication. The latter level involves leadership internal corporate communication between senior managers and all employees, and is a key concern of the current study because of the study's focus on organisational level engagement. Internal corporate communication is defined as: 'communication between an organisation's strategic managers and its internal stakeholders, designed to promote commitment to the organisation, a sense of belonging to it, awareness of its changing environment and understanding of its evolving aims' (Welch \& Jackson 2007, p.193). Whilst presented as predominately one-way, the internal corporate communication concept calls for senior managers to encourage upward critical communication (Tourish \& Robson, 2006) and underpin leadership communication with two-way symmetrical communication (Grunig \& Hunt, 1984) to provide opportunities for dialogue.

Dialogue is a crucial aspect of senior management leadership communication. Johansson, Miller and Hamrin (2014, p. 154) identify a number of principles of communicative leadership, including: 'communicative leaders are willing to listen, receive questions or complaints, and share appropriate information in a truthful and adequate manner'. According to Neill (2015) millennials also expect more dialogue in internal communication. Illes and Mathews (2015) state that employees want to see their leaders in person and in action. Men (2014, p. 259) states that: 'transformational leaders convey a strong sense of purpose and collective mission and motivate employees by communicating inspirational vision and high performance expectations'. However, this approach is critiqued by Tourish (2013) as it cannot be assumed that goals proposed by leaders are necessarily of mutual benefit to employees. Furthermore, Tourish $(2013$, p. 28$)$ argues that the transformational leadership model: 'tends to preclude the possibility of corrective feedback from followers to leaders'.

Fairhurst and Uhl-Bien (2012) argue for a relational view of leadership where it is seen not as a trait or behaviour, but as a phenomenon generated in the interactions among people acting in context. At the core of this view is the assumption that leadership is co-constructed in social interaction processes and Fairhurst and Uhl-Bien conclude that communication is a key element of relationally-oriented leadership. This has parallels with a 'discursive leadership' approach (Carroll \& Gillen, 1987, p.41) focused on unplanned, informal and brief conversations. Walker and Aritz (2014, p. 13) suggest that this approach to leadership means that communication becomes 'the primary concern rather than a secondary or tertiary consideration'. However, there appears to be a gap between this aspiration and practice as Nilsson (2010) found that senior managers expected messages to be transferred from sender to receiver, not co-created. 
Kent and Taylor (2002) set out five dimensions for dialogue in public relations: mutuality, the acknowledgement that organisations and publics are inextricably linked; propinquity, the willingness and capacity of publics to express their demands to the organisation, and the latter's ability to consult the former regarding matters of mutual interest; empathy, the atmosphere or environment required for fruitful dialogue; risk, the fact that the outcome of a dialogic process may be unpredictable; and commitment, the parties to the dialogue must be truly committed to real conversation. Theunissen and Noordin (2012) suggest that effective dialogue is based on four premises, namely that participants act authentically, that they focus on the future while allowing change to occur, collaborate and share insights and knowledge, and that they are present within the dialogical process. However, Gutiérrez-García, Recalde and Piñera-Camacho (2015) point out that although the term "dialogue" has been part of the lexicon of public relations for many years, no clear consensus has yet emerged as regards its definition, and there has been little research into its applications or the management processes involved. In terms of practice, Taylor and Kent (2014) contend that many communication professionals erroneously conclude that dialogue is impossible because there is too much risk to organisations, because it is too time consuming, or because senior management does not see the value. Furthermore they argue that dialogue will not be possible until two related conditions are met: (a) public relations professionals are trained in how to facilitate dialogue and (b) management becomes convinced of its value. Cardwell, Williams and Pyle (2016) state that their finding that younger public relations practitioners are concerned solely with external communication may present an obstacle to achieving professionalism in the field if the future generation is not trained in the managerial processes of advising executive leaders and balancing internal stakeholder needs.

The challenge of facilitating dialogue between internal stakeholders and senior managers provides an opportunity for internal corporate communication professionals. To complement line management voice channels, strategic internal communication managers can promote opportunities for upward critical communication and dialogue via employee voice channels such as: organisation-wide team briefing meetings, with opportunities for discussion; senior management question and answer events; interactive online sessions; listening lunches; anonymous employee surveys; and, suggestion schemes of various kinds.

\section{Employee voice and silence}

While the concept of employee voice has attracted considerable attention in recent years, it has a long history within a range of disciplines, resulting in elastic understandings of the concept (Wilkinson, Donaghey, Dundon \& Freeman, 2014). In practical terms, an employee can exercise voice by chatting to colleagues over coffee; by raising a work issue with their line manager; or by expressing an opinion in an annual employee survey. Likewise, the employee can exercise silence by withholding an idea in a project meeting; by holding back on asking a question at a meet-the-CEO event; or by not mentioning criticisms in an engagement survey. While academic perspectives of the concepts of employee voice and silence differ, Van Dyne, Ang and Botero (2003, p. 1363) provide an influential definition of employee voice as intentionally expressing work related ideas, information and opinions; and employee silence as intentionally withholding work related ideas, information and opinions. They argue that both voice and silence are multidimensional concepts involving three types of 
behaviour: acquiescent (disengaged behaviour, based on resignation and feeling unable to make a difference); defensive (self-protective behaviour based on fear and feeling at risk); and, prosocial (other-orientated behaviour based on cooperative, altruistic feelings).

Brinsfield (2014) traces the history of the employee voice and silence concepts from Hirschman's 1970s consumer behaviour work on exit, voice and loyalty; through Farrell's (1983) application of the concept to employees; to Van Dyne et al.'s (2003) work on employee silence and voice. Brinsfield (2014) notes parallel developments in other fields including Roberts and O'Reilly's (1974) work on upward communication in the context of their organisational communication scale development. In an earlier work, Brinsfield et al. (2009) provided an overview of employee voice and silence work in three waves from 1970 to 2003. The initial wave includes work conducted in the 1970s and 1980s on topics such as voice and exit, and spirals of silence; the second wave in the 1990s includes work on whistle blowing and deaf ear syndrome; the final wave includes work in the 2000s on topics such as organisational silence, employee silence, and voice and silence as multidimensional constructs.

Kaufman (2014, p. 18), reporting on the early (pre-Hirschman) history of the employee voice concept says: 'the idea of employee voice goes back more than two centuries to the start of the Industrial Revolution'. Kaufman notes that the rich early literature on employee voice seems to have been overlooked by scholars who see the concept as being introduced by Hirschman (1970) and developed by Freeman and Medoff (1984).

Consequently, useful additions to Brinsfield et al.'s (2009) overview include the early history of the concept and in particular, Freeman and Medoff's (1984) work since they have been credited with popularising the term voice (Wilkinson et al., 2004). Historical accounts of the employee voice concept trace its usage in the context of trade unions and collective representation of employees, works councils and industrial democracy (Kaufman, 2014). Additionally, the term voice has previously been used to indicate co-operative employee behaviour. For example management writer Handy (1985, p. 44) discusses co-operative psychological contracts in which employees identify with the goals of the organisation, become more creative in the pursuit of those goals, consequently being provided with rewards including: 'more voice in the selection of the goals and more discretion in the choice of means to achieve them.' This management-centric view conceptualises voice as something management bestows on employees, they are allowed to contribute. Alternatively, an employee-centric view of voice may conceptualise voice is as discretionary employee communication behaviour, they decide whether to contribute. Two aspects of voice are of particular interest to this study, upward voice from employees, and senior management receptiveness.

\section{Upward communication from employees}

Upward communication can involve opportunities for employees and managers to exchange views about issues, as well as upward problem-solving with opportunities for employees to provide feedback on specific topics (Wilkinson et al., 2004). Line managers, middle managers and senior managers are all potential recipients of upward communication from employees. Roberts and O'Reilly's (1974) included upward communication in their organisational communication scale. However, their questionnaire items relate to line managers and senior 
managers are not included in the instrument. Ensuring senior managers receive critical upward feedback from employees has been identified as a key concern for healthy organisations (Tourish \& Robson, 2006). Tourish and Robson (2006) argue that critical upward communication is valuable to organisations because it provides a potential safeguard against unrealistic senior management views of opinion within their organisations. They observe reluctance to engage in upward critical feedback on the part of employees due to fears about retaliation from managers. They highlight a tendency for managers to hyper-scrutinize critical feedback; while treating positive upward feedback in the opposite manner. These authors consider informal upward communication and call for the development of additional methods of communication capable of facilitating contact between senior managers and employees. They argue that critical upward feedback should be thoroughly institutionalised into organisational life. One way this could be facilitated is by ensuring formal internal corporate communication methods are designed to maximise opportunities for critical employee voice.

\section{Senior management receptiveness to employee voice}

If employees perceive that senior managers don't want to hear their views, and observe management turning a "deaf-ear" to them, they may be deterred from exercising voice. Beugré (2010) posits that "deaf-ear" syndrome could discourage voice and possibly result in employee disengagement. Likewise, if employees view voice calls within their organisation as a sham, and suspect managers of going through the motions of consultation without real commitment to listening, frustration (Price et al., 2001 cited in Beugré, 2010), disillusionment and disengagement could ensue. Since a tendency to demonize and even punish dissenting employees is evident (Tourish \& Robson, 2006); exercising upward critical voice can involve employees placing their feelings of psychological safety at risk. As noted in the organisational engagement section of this review, psychological safety is one of the conditions Kahn (1990) identified as necessary for the development of personal engagement.

Exercising employee voice is one element of internal communication. Senior management commitment to listening and responding to employee voice is the other side of the coin. While Truss et al. (2006) found that having opportunities to feed views upwards was one of the three most important factors for engagement, Purcell and Hall (2012, p. 3) assert that: 'Having a voice, and being listened to, is one of the most important antecedents of engagement' (emphasis added). This suggests research questions for the present study:

Research question 1: How satisfied are employees with opportunities for upward employee voice? Research question 2: How receptive are senior managers in terms of listening and responding to employees?

The act of contributing work related ideas, information and opinions could be considered as an indicator of employee engagement. However, engaged employees may hold back if they feel it is unsafe to contribute due to potential risks and repercussions; resulting in a perception that it is risky to exercise employee voice. The following section on employee engagement includes consideration of this issue of psychological safety as one of the conditions of organisational engagement. 


\section{Organisational engagement and the communication-engagement connection}

Rees et al. (2013) claim that employee voice is significantly related to engagement. However, further research is needed in this area as Gruman and Saks argue that: 'relatively little attention has been given to the relationship between voice and engagement' (2014, p. 459). Additionally, there is a need for research into relationships between internal communication and engagement (Reissner \& Pagan, 2013). To inform the empirical work, this section of the literature review sets out the study's understanding of the employee engagement and organisational engagement concepts. The review includes consideration of a communication-engagement conceptual model (Welch, 2011) which contributes to the conceptual framework for this study.

Employee engagement has become a key concern for leaders of organisations and has attracted increasing scholarly interest. The concept is understood in a variety of ways by practitioners, with multiple understandings of the term circulating in organisations. Balain and Sparrow (2009) report a survey which found 20 different models of engagement inside one single organisation. Scientific understanding of employee engagement is also variable as outlined by Welch (2011) who depicted the evolution of the concept in three waves as briefly summarised next.

Kahn's $(1990,1992)$ seminal academic work on personal engagement signalled the start of Wave 1 1990-1999. Kahn (1990, p. 694) contributed an influential definition of personal work engagement as: 'the harnessing of organizational members' selves to their work roles; in engagement, people employ and express themselves physically, cognitively, and emotionally during role performance.' Kahn's work indicates that certain psychological engagement conditions are necessary for engagement: meaningfulness (work elements); safety (social elements, including management style, process and organisational norms); and, availability (individual distractions). As mentioned above, perceptions of psychological safety may influence employee willingness to contribute work-related ideas, information and opinions. Psychological safety is influenced by social conditions such as the organisation's norms, group dynamics and management style (Kahn, 1990). Alongside this academic work, practitioner work popularised the term employee engagement, which has been attributed to consultancy firm Gallup (Endres \& Mancheno-Smoak, 2008; Little \& Little, 2006; Schaufeli \& Bakker, 2010). Gallup's Buckingham and Coffman (1999) briefly mentioned employee engagement and defined a fully engaged employee as one who could answer yes to all 12 questions on Gallup's workplace questionnaire. Shuck and Wollard (2010) assert that this caused an overnight sensation amongst business people and prompted demand for employee engagement consultancy services.

Consultancy firm offerings grew alongside academic interest in Wave 2 2000-2005. For example, consultants, Hewitt Associates (2004, p. 2) measured employee engagement with an 18 item scale and defined it as: 'the state in which individuals are emotionally and intellectually committed to the organization or group, as measured by three primary behaviors: Say...stay...strive.' In academic work, the emergence of the positive psychology movement switched focus from negative consequences of work attitudes such as job burnout, to positive drivers like engagement. This triggered fresh scientific work on engagement (Maslach, Schaufeli \& Leiter, 2001; Harter, Schmidt \& Hayes, 2002; Luthans \& Peterson, 2002; May, Gilson \& Harter, 2004) including Schaufeli and 
Bakker's (2004) influential definition of job engagement in the context of organisational behaviour: 'a positive, fulfilling, work-related state of mind that is characterized by vigor, dedication, and absorption' (p. 295). This and Kahn's (1990) definition arguably share a common focus on the manifestations of engagement: cognitive absorption; emotional - dedication; and, physical - vigour (Welch, 2011; Schaufeli, 2014).

Saks (2006) contributed to the increasing volume of scientific work evident in Wave 3 2006-2010 with an examination of the status of the concept which addressed fears that it was more of a buzzword than a serious construct. He provides a convincing argument for engagement as a scientific concept and inspired further scholarly effort. In particular, Saks extended the employee engagement concept to encompass both job engagement and organisation engagement. At the same time practitioner and professional body interest in engagement grew. For example, in the UK the Chartered Institute of Personnel and Development (CIPD) produced a survey report (Truss et al., 2006) entitled 'How engaged are British employees?' Two engagement handbooks were published in 2010, one on work engagement (Bakker \& Leiter, 2010) the other on employee engagement (Albrecht, 2010). In the latter handbook, Kahn (2010) considers the essence of engagement and emphasises its dynamic nature as opposed to steady-state motivation theory characterising employees as either motivated or not motivated.

Welch's (2011) view of the evolution of employee engagement theory is summarised in Table 1:

Table 1: Welch's (2011) view of the evolution of employee engagement theory

\begin{tabular}{lcl}
\hline Evolutionary stage & Time span & Influential developments \\
\hline Wave 1 & $1990-1999$ & $\begin{array}{l}\text { Kahn's (1990, 1992) seminal academic work on personal engagement; } \\
\text { Gallup's Buckingham and Coffman (1999) ignite business interest in the } \\
\text { concept of employee engagement. } \\
\text { Wave } 2 \\
\text { Consultancy firm offerings develop, such as Hewitt Associates (2004); } \\
\text { alongside growth in academic interest including Schaufeli and Bakker's } \\
\text { Wave 3 } 2000-2005 \text { (2004) work on job engagement } \\
\text { Saks (2006) extended the employee engagement concept to encompass } \\
\text { organisation engagement. Two scholarly handbooks published, one on } \\
\text { work engagement (Bakker \& Leiter, 2010) the other on employee } \\
\text { engagement (Albrecht, 2010). }\end{array}$ \\
\hline
\end{tabular}

Taking account of the previous waves of engagement work, Welch (2011, p.335) defines employee engagement as: 'cognitive, emotional and physical role performance characterised by absorption, dedication and vigour and dependent upon the psychological conditions of meaningfulness, safety and availability.' Welch goes on to reiterate Saks's (2006) view that the focus of engagement can include job engagement and organisational engagement. Saks (2006, p. 604) built on Kahn's (1990) work to extend the engagement concept to organisation as well as job engagement, noting that engagement: 'reflects the extent to which an individual is psychologically present in a particular organizational role. The two most dominant roles for most organizational members are their work role and their role as a member of an organization.' Welch (2011, p. 341) offers this view of organisational engagement: 'a dynamic, changeable psychological state which links employees to their organisations, manifest in employee role performances expressed physically, cognitively and emotionally, and influenced by organisation level internal communication.' 
Connections between organisational engagement and organisational level communication are suggested in Welch's (2011) communication-engagement conceptual model. The model provides a communication perspective of engagement and contributes to the conceptual framework for the empirical study outlined in this paper. The model integrates the internal corporate communication dimension of internal communication with components of engagement (emotional / dedication; cognitive / absorption; physical / vigour / behaviour), and Kahn's (1990) three psychological conditions for engagement (safety, availability and meaningfulness).

Since employee voice is an aspect of employee communication behaviour, and engaged employees are likely to intentionally express constructive work related ideas, information and opinions, a further research question and associated hypotheses for this study arise. The hypotheses enable investigation of the intuitively appealing point of view asserted by Rothmann (2014, p. 176) that: 'two-way communication, characterised by sharing of information and asking for feedback from all levels of an organisation, drives employee engagement.'

Research question 3: To what extent are employee voice and organisational engagement linked? Hypothesis 1: There will be a significant and positive relationship between employee voice and organisational engagement.

Hypothesis 2: There will be a significant and positive relationship between employee satisfaction with opportunities for upward employee voice and emotional organisational engagement.

Hypothesis 3: There will be a significant and positive relationship between senior manager receptiveness and emotional organisational engagement.

The discussions in this review lead to a conceptual framework model for the empirical study depicted in Figure 1. Consideration of the methodology undertaken to explore the research questions and hypotheses identified in this review follows.

\section{[Positioned about here]}

Figure 1: Communication - voice - engagement conceptual framework model.

\section{Methodology}

A cross-sectional survey design was used for the study featuring a self-administrated online questionnaire. The exploratory design of the questionnaire has been influenced by issues discussed in the conceptual framework above and by previous work on internal communication and employee voice (Hargie \& Tourish, 2009; ZwijzeKoning \& de Jong, 2007), employee engagement and organisational engagement (Kahn, 1990; Saks, 2006), and draws on elements of the UK Workplace Employment Relations Survey (WERS) (2011).

While the questionnaire design adapts and adopts elements from previous work, it also attempts to develop aspects of previous instruments. For example, writers (Hargie \& Tourish, 2009; Zwijze-Koning \& de Jong, 2007) note that existing instruments such as Downs and Hazen's (1977) Communication Satisfaction Questionnaire (CSQ) do not directly address top management communication. Consequently, the questionnaire used in this 
study enables participants to specifically rate senior management communication performance. The inclusion of descriptors such as highly engaged in Saks's (2006) organisational engagement instrument questions seem unnecessary as the Likert-type scale enables expressions of strength of feeling. In line with previous practice (e.g. Hargie \& Tourish, 2009), an assurance that all answers are confidential was provided.

The design of the questionnaire provides the basis for precise estimates of the degree of relationship between communication and engagement. However, Bryman and Bell (2007) argue that measurement processes may possess an artificial sense of accuracy and the analysis of relationships between variables creates a static view of social life that is independent of peoples' lives. While questionnaires offer researchers a valuable method of gauging employee views, they are limited in their ability to probe issues in-depth such as the significance that people attach to actions such as senior manager receptiveness to employee voice.

\section{Measures}

Employee voice was explored via a series of questionnaire items relating to the two aspects highlighted in the literature review: upward communication from employees and senior management receptiveness to employee voice. Employee views on upward communication were measured by three items which asked participants to indicate their satisfaction with the following: 1) Opportunities to feed my views upwards; 2) Ways for me to pass on criticisms; and, 3) Ways for me to communicate ideas to senior management (5=Very satisfied, 1=Very dissatisfied). The first of these items is based on a participation item in an employee attitudes and engagement instrument (Truss et al. 2006), the remaining items are derived from an organisational dissent measure (Kassing 1998). Employee views on senior manager receptiveness were also measured by three items. Participants were asked to rate how good the senior management team at the organisation are at: 1) Seeking the views of employees or employee representatives; 2) Responding to suggestions from employees or employee representatives; and, 3) Allowing employees or employee representatives to influence final decisions (5=Very good, 1= Very poor). The items were adopted from the WERS (2011) study.

The employee engagement section of the questionnaire was influenced by Saks's (2006) organisation engagement approach which was synthesised with Khan's (1990) view of engagement to generate 20 items to indicate cognitive, emotional and behavioural organisational engagement. Participants were asked: To what extent do you agree or disagree with the following statements about working here? (5=Very strong agreement, $1=$ Very strong disagreement). The statements were in three categories. Behavioural organisational engagement (7 items; $\alpha$.87) items include: I put extra energy into helping achieve Organisation Name's aims. Cognitive engagement was assessed with 6 items ( $\alpha$.86) including: I'm interested in what happens at Organisation Name. Emotional organisational engagement was gauged with 7 items ( $\alpha .91)$ including: I care about the future of Organisation Name. The instrument was tested and face validity was established via a small scale prior study. A summary of the measures is shown in Table 2. 
Table 2: Summary of measures

\begin{tabular}{|c|c|c|}
\hline $\begin{array}{l}\text { Communication and } \\
\text { engagement elements }\end{array}$ & Measures & Scales \\
\hline $\begin{array}{l}\text { Upward } \\
\text { communication }\end{array}$ & $\begin{array}{l}\text { 1. Opportunities to feed my views upwards } \\
\text { 2. Ways for me to pass on criticisms } \\
\text { 3. Ways for me to communicate ideas to senior } \\
\text { management }\end{array}$ & $\begin{array}{l}\text { 1=Very dissatisfied, 5=Very } \\
\text { satisfied. }\end{array}$ \\
\hline $\begin{array}{l}\text { Senior manager } \\
\text { receptiveness }\end{array}$ & $\begin{array}{l}\text { 1. Seeking the views of employees or employee } \\
\text { representatives } \\
\text { 2. Responding to suggestions from employees or } \\
\text { employee representatives } \\
\text { 3. Allowing employees or employee representatives } \\
\text { to influence final decisions }\end{array}$ & 1= Very poor, 5=Very good. \\
\hline $\begin{array}{l}\text { Organisational } \\
\text { engagement }\end{array}$ & $\begin{array}{l}\text { 1. Cognitive organisational engagement (6 items). } \\
\text { Example: I'm interested in what happens at } \\
\text { Organisation Name. } \\
\text { 2. Emotional Organisational Engagement (7 items). } \\
\text { Example: I care about the future of Organisation } \\
\text { Name. } \\
\text { 3. Behavioural Organisational Engagement ( } 7 \text { items). } \\
\text { Example: I put extra energy into helping achieve } \\
\text { Organisation Name's aims. }\end{array}$ & $\begin{array}{l}1=\text { Very strong disagreement, } \\
5=\text { Very strong agreement. }\end{array}$ \\
\hline
\end{tabular}

\section{Data Collection}

The questionnaire was administered in five organisations. Three organisations are in the public sector; a shared services function within a UK government ministerial department and two local borough councils in the south of England. One organisation is in the not-for-profit sector; a housing association based in England. The fifth organisation is in the private sector; a group services department in a major UK bank. The two local authorities and the housing association are medium sized organisations, employing between 800 and 1000 people. In one local authority agreement could not be secured for everyone in the council to be invited to participate, so two departments were chosen within the organisation. The UK government ministry and the UK bank are two very large organisations and specific departments within each organisation were chosen for the research. In all cases everyone in the chosen department or organisation was invited to participate in the survey. The total number of respondents was 2066 and the response rate was 36 per cent. In the case of the UK bank, their Global Services department participated and included employees located outside the UK. In all other cases, respondents are UK based.

\section{Analysis}

The study explored Research Question 1 (How satisfied are employees with opportunities for upward employee voice?) using three items to indicate upward employee voice via a Likert-type scale $(1=$ Very dissatisfied; $5=$ Very satisfied). The results (Table 3; items 1-3) show the highest satisfaction was for 'Opportunities to feed my views upwards' at $3.42(\mathrm{SD}=0.90)$. The mean level of satisfaction with 'Ways for me to communicate ideas to senior managers' was 3.38 (SD=0.94). The findings for these two items are similar to those found by Rees et al. (2013) in two UK based companies. Satisfaction with 'Ways to pass on criticisms' (3.30, SD=0.92) had the lowest satisfaction level of the three upward communication items. These results indicate a moderately positive level of satisfaction with employee voice. 
In addressing Research Question 2 (How receptive are senior managers in terms of listening and responding to employees?), the findings (Table 3; items 4-6) show that 'Senior managers seeking views' and 'Senior managers responding to suggestions' are rated at $3.44(S D=0.97)$ and $3.39(S D=0.95)$ respectively $(1=$ Very poor; $5=$ Very good).These results are similar to the satisfaction levels reported above for two of the upward communication items. The rating for 'Senior managers allowing employees/employee representatives to influence final decisions' is the lowest of the employee voice items (3.24, SD=0.99). This finding is comparable with WERS 2011 findings, where satisfaction with management allowing employees and representatives to influence decisions was also lower than satisfaction with responding to suggestions and seeing views (Van Wenrooy, Bewley, Bryson, Forth, Freeth, Stokes \& Wood, 2013). Relatively low levels of satisfaction with senior manager receptiveness to voice may reflect what Tourish (2013) describes as a flaw in transformational leadership which precludes the possibility of corrective feedback from followers to leaders. The reasons for low levels may be attributable to a number of factors, including fear of feedback, problems of ingratiation and selfefficacy biases (Tourish, 2013). Leaders may also exaggerate the frequency of critical feedback. According to Tourish (2013, p. 85): 'on the relatively rare occasions when leaders, particularly those in senior positions, do receive critical upward feedback, they experience it as a striking and, hence, memorable event. They are likely to pay it special attention - it remains vividly in their memory and so convinces them it is more typical an event than it actually is'. Low levels of satisfaction with senior managers responding to suggestions can be considered symptomatic of an approach to employee engagement that is predominantly rooted in a discourse of compliance where communication is primarily monovocal and reflective of management interests (Francis, Ramdhony, Reddington \& Staines, 2013). 
Table 3. Employee voice and organisational engagement: Means, standard deviations and correlations

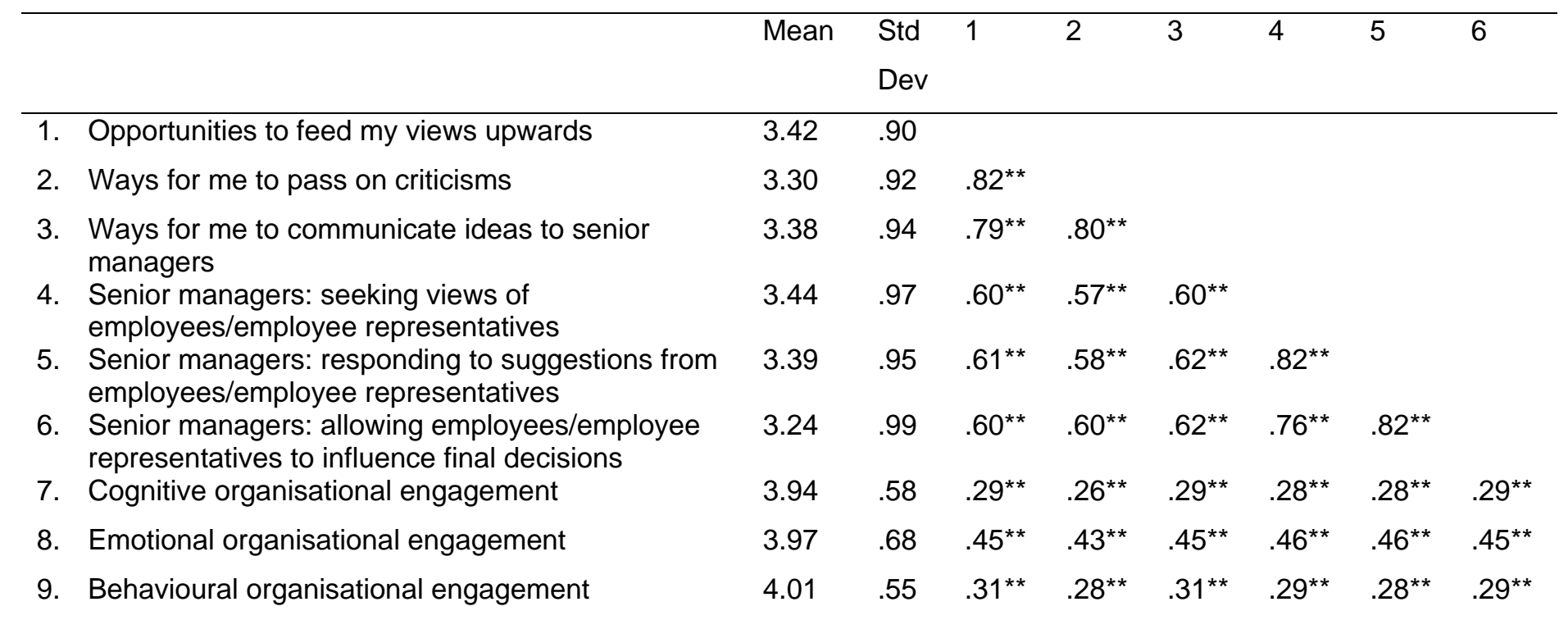

Employee voice items 1-3: upward communication ( $1=$ Very dissatisfied, 5 = Very satisfied). Employee voice items 4-6: senior manager receptiveness $(1=$ Very poor, $5=$ Very good $)$. Organisational engagement: cognitive organisational engagement (item 7); emotional organisational engagement (item 8); and, behavioural organisational engagement (item 9). ${ }^{*}$ Correlation is significant at the .01 level (2-tailed). $\mathrm{N}=2066$

Research Question 3 (To what extent are employee voice and organisational engagement linked?) was examined via three hypotheses. Correlation analysis was conducted to investigate Hypothesis 1 (There will be a significant and positive relationship between employee voice and organisational engagement). The results indicate that the aspects of employee voice included in this study are positively and statistically significantly $(p<$ .01) associated with the study's indicators of cognitive, emotional and behavioural organisational engagement (Table 3, items 7-9). The strongest relationship was with emotional organisational engagement. The findings on associations between employee voice and organisational engagement reinforce results in other studies that suggest that involvement and participation are linked to engagement (Purcell, Kinnie, Hutchinson, Rayton \& Swart, 2003; Robinson, Perryman \& Hayday, 2004; Truss et al., 2006). Rees et al. (2013, p. 2790) found that employee voice is correlated with work engagement $(r=.55, p<.01)$. The current study seeks to build on Saks's (2006) work which distinguished between job and organisational engagement and the findings indicate positive associations between employee voice and organisational engagement. Organisational engagement has not been sufficiently included in other studies. The results indicate some potential support for Purcell's (2014, p. 238) argument that it is 'more helpful to delineate between job and organizational engagement' than between 'state' and 'behavioural engagement'.

The employee voice items are most strongly associated with emotional organisational engagement in this study. Emotional organisational engagement correlations (Table 3, item 8) range from $r=.43$ to $r=.45$ for the three upward communication items and from $r=.45$ to $r=.46$ for the three senior manager receptiveness items. This may imply that upward communication and senior manager receptiveness are most strongly associated with positive feelings towards the organisation. This may be because exercising employee voice leads employees to 
feel more valued as individuals, providing a deeper, mature, 'adult to adult' level of communication within the organisation. Alternatively, it may indicate that employees with a greater sense of emotional organisational engagement are more likely to exercise their voice. Either way, the interplay may contribute to a social exchange based relationship (Saks, 2006), one that generates a sense of fairness leading to relational trust, fostering reciprocity and an emotional bond (Rees et al., 2013). The associations with emotional organisational engagement suggest that senior managers who do not have a dialogue with employees may be limiting potential improvements in organisational engagement. As Tourish points out (2013, p. 80): 'People cannot be viewed as passive recipients for information. They are active and questioning agents in the process of decision making. To ignore this, as a display of leader power, is to violate one of the most fundamental traits of our being.'

Standard multiple regression analysis was performed between emotional organisational engagement as the dependent variable and all six employee voice items as independent variables (Table 4). The adjusted squared multiple correlation was significantly different from zero $(F=133.899, p<.01)$ and 27.9 per cent of the variation in emotional organisational engagement was explained by the set of independent variables. All the independent variables, except 'Satisfaction with ways to pass on criticisms' $(t=1.264, p=.206)$, were found to significantly and positively contribute to the prediction of emotional organisational engagement, namely, 'Senior managers seeking views of employees' $(t=4.395, p=.000)$, 'Senior managers responding to suggestions' $(t=2.074, p=$ .038), 'Senior managers allowing employees to influence decisions' ( $t=2.748, p=.006)$, 'Satisfaction with opportunities to feed views upwards' $(t=3.528, p=.000)$, and 'Satisfaction with ways to communicate ideas to senior managers.' ( $t=3.127, p=.002)$. The data satisfied the assumptions of multicollinearity, normality of residuals, and homoscedasticity while no outliers were identified.

Table 4. Multiple regression: predictors of emotional organisational engagement.

\begin{tabular}{|c|c|c|c|}
\hline \multirow[b]{2}{*}{ Variable } & & \multicolumn{2}{|c|}{$\begin{array}{c}\text { Emotional } \\
\text { organisational } \\
\text { engagement }\end{array}$} \\
\hline & & B & Std. Error \\
\hline Constant & & $2.391^{* \star}$ & .056 \\
\hline $\begin{array}{l}\text { Senior managers: seeking views of employees/employee } \\
\text { representatives (SMR) }\end{array}$ & & $.110^{* *}$ & .025 \\
\hline $\begin{array}{l}\text { Senior managers: responding to suggestions from } \\
\text { employees/employee representatives (SMR) }\end{array}$ & & $.060^{*}$ & .029 \\
\hline $\begin{array}{l}\text { Senior managers: allowing employees/employee representatives to } \\
\text { influence final decisions (SMR) }\end{array}$ & & $.068^{\star *}$ & .025 \\
\hline Opportunities to feed my views upwards (UC) & & $.099 * *$ & .028 \\
\hline Ways for me to pass on criticisms (UC) & & .035 & .028 \\
\hline Ways for me to communicate ideas to senior managers (UC) & & $.081^{\star *}$ & .026 \\
\hline $\begin{array}{l}\mathrm{R}^{2}(\operatorname{adj}) \\
\mathrm{F}\end{array}$ & $\begin{array}{c}.279 \\
133.899 * *\end{array}$ & & \\
\hline
\end{tabular}

Note: Independent variables: Upward communication items (UC) and senior manager receptiveness items (SMR). Dependent variable: emotional organisational engagement. $N=2066 .{ }^{*} p<.05 .{ }^{* \star} p<.01$. 
Multiple regression analysis indicates that 27.9 per cent of the variability in emotional organisational engagement can be explained by five out of six aspects of internal communication tested. The 'Senior management seeking views of employees' coefficient reveals that for any increase in this dimension (from 1 to 5 ) there is also an increase in the level of emotional organisational engagement equal to .110, when the other variables are constant. When looking at the other two dimensions of satisfaction with opportunities for upward employee voice, "Senior management responding to suggestions", and "Senior management allowing employees to influence decisions", the coefficients are slightly lower; thus, for any change in these two dimensions there is also a positive change in emotional organisational engagement equal to, respectively .060 and .068, when the other variables are constant. Therefore, Hypothesis 2 (There will be a significant and positive relationship between employee satisfaction with opportunities for upward employee voice and emotional organisational engagement) is supported.

The "Satisfaction with opportunities to feed views upwards" coefficient shows that for any increase in this dimension (from 1 to 5), there is also a positive increase in emotional organisational engagement equal to .099, keeping the other variables constant. Similarly, any change in "Satisfaction with ways to communicate ideas to senior management" leads to a positive change in emotional organisational engagement equal to .081 , controlling for all the other variables. The result for 'satisfaction with ways to pass on criticisms' was not statistically significant. Therefore, Hypothesis 3 (there will be a significant and positive relationship between senior manager receptiveness and emotional organisational engagement) is partially supported.

\section{Conclusion}

This paper contributes consideration of fresh data via initial analysis of a sizable dataset. The dataset includes information from participants in public, private and not-for-profit sector UK-based organisations. However, the findings are not generalisable as they are not representative of the general workforce. While the analysis procedures used here show important linkages, they cannot establish causality. The instrument designed for this exploratory study yielded valuable data on internal communication, employee voice, and organisational employee engagement. However, it requires further examination to determine its usefulness in a variety of settings. Future quantitative research could submit the instrument to further testing, undertake additional statistical procedures, or conduct comparative research by organisational type. In addition, the issues explored here would benefit from scrutiny via qualitative research approaches.

The study found only moderately positive employee satisfaction with both dimensions of employee voice (upward communication; senior manager receptiveness). This may suggest that employee voice is not fully utilised as an internal corporate communication process in the five organisations that participated in the research. The associations between both dimensions of voice and the three levels of organisational engagement (cognitive, emotional and behavioural) are positive and statistically significant. In this study, these dimensions of employee voice can be considered potential antecedents to emotional organisational engagement. This paper addresses a gap in the literature relating to the communication-engagement connection. It is noteworthy that the 
study found stronger correlations with its indicator of emotional organisational engagement than those for cognitive and behavioural organisational engagement.

The findings highlight upward employee voice and senior manager receptiveness to voice as valuable areas for internal communication scholarship. The study's findings have potential implications for internal communication practice. Internal communication managers may consider including specific employee voice objectives within their strategic plans. This could include enhancing opportunities for upward employee voice. The study's findings indicate a need to complement upward employee voice initiatives with strategic efforts to encourage senior manager receptiveness to voice. This could involve practitioners developing strategic and tactical employee voice capabilities, including the design and management of systems for upward communication. Such systems can include a range of methods including face-to-face (for example, meet the CEO type events; senior management Q\&A sessions) and online (for example, the facilitation of discussions on Enterprise Social Networks; the analysis of common threads or issues highlighted in internal blogs and wikis; online surveys and polls). Furthermore, to maximise their strategic impact, internal communication practitioner capabilities could also incorporate coaching senior managers to enable them to reach their potential to seek employee views and respond to suggestions. This also has implications regarding the communication competence and skills of senior managers; listening and responding to voice are important aspects of their role as leaders. The study's findings suggest that paying attention to both sides of the employee voice coin is necessary to realise the potential of organisational employee engagement. 


\section{References}

Albrecht, S. L. (2010) (Ed) Handbook of employee engagement: Perspectives, issues, research and practice. Cheltenham: Edward Elgar.

Bakker, A. B., \& Leiter, M. P. (2010) (Eds) Work engagement: A handbook of essential theory and research. Hove: Psychology Press.

Balain, S., \& Sparrow, P. (2009) Engaged to Perform: A new perspective on employee engagement. Centre for Performance-led HR White Paper 09/04. Management School: Lancaster University.

Beugré C. D. (2010) Organizational conditions fostering employee engagement: the role of "voice". In Albrecht, S. L. (Ed) (2010) Handbook of employee engagement: Perspectives, issues, research and practice (pp. 174-181). Cheltenham: Edward Elgar.

Brinsfield, C. T. (2014) Employee voice and silence in organizational behavior. In Wilkinson, A., Donaghey, J., Dundon, T., \& Freeman, R. (Eds.) (2014) Handbook of Research on Employee Voice (pp. 114-131). Cheltenham: Edward Elgar.

Brinsfield, C. T., Edwards, M. S., \& Greenberg, J. (2009) Voice and silence in organizations: Historical review and current conceptualizations. In Greenberg, J. \& Edwards, M. (Ed.), Voice and silence in organizations. Bingley: Emerald.

Bryman, A., \& Bell, E. (2007) Business Research Methods. Second Edition, Oxford: Oxford University Press.

Buckingham, M., \& Coffman, C. (1999) First, break all the rules: What the world's greatest managers do differently. The Gallup Organization. New York: Simon \& Schuster.

Cardwell, L.A., Williams, S. \& Pyle, A. (2016) Corporate public relations dynamics: Internal vs. external stakeholders and the role of the practitioner. Public Relations Review. 43(1), pp.152-162

Carroll, S.J., Gillen, D.J. (1987) Are classical management functions useful in describing managerial work? Academy of Management Review, 12(1), pp.38-51.

Dickson, D. A., Rainey, S., \& Hargie, O. D. (2003) Communicating sensitive business issues: Part 1. Corporate Communications: An International Journal, 8(1), 35-43.

Downs C. W., \& Adrian, A. D. (2004) Assessing organizational communication. New York: Guilford Press.

Downs, C. W., \& Hazen, M. D. (1977) A factor analytic study of communication satisfaction. Journal of Business Communication, 14(3), 63-73.

Endres, G. M., \& Mancheno-Smoak, L. (2008) The human resource craze: human performance improvement and employee engagement. Organizational Development Journal, 26(1), 69-78.

Fairhurst, G.T., Uhl-Bien, M. (2012) Organizational discourse analysis (ODA): Examining leadership as a relational process. The Leadership Quarterly. 23(6), pp.1043-1062.

Farrell, D. (1983) Exit, voice, loyalty, and neglect as responses to job dissatisfaction: A multidimensional scaling study. Academy of Management Journal, 26(4), 596-607.

Francis, H.M., Ramdhony, A., Reddington, M., \& Staines, H. (2013) Opening spaces for conversational practice: a conduit for effective engagement strategies and productive working arrangements. The International Journal of Human Resource Management. 24(14), 2713-2740.

Freeman, R., \& Medoff, J. (1984) What do Unions do? New York: Basic Books. 
Gruman, J.A., \& Saks, A. (2014) Being psychologically present when speaking up: employee voice engagement. In Wilkinson, A., Donaghey, J., Dundon, T., Freeman, R.B (Eds) Handbook of Research on Employee Voice, Cheltenham: Edward Elgar.

Grunig, J. E., \& Hunt, T. (1984) Managing public relations. New York: Holt, Rinehart and Winston.

Gutiérrez-García, E., Recalde, M. \& Piñera-Camacho, A. (2015) Reinventing the wheel? A comparative overview of the concept of dialogue. Public Relations Review, 41(5), pp.744-753.

Handy, C. (1985) Understanding Organizations. London: Penguin Books.

Hargie, O. D., \& Tourish, D. (1993) Assessing the effectiveness of communication in organisations: the communication audit approach. Health Services Management Research, 6(4), 276-285.

Hargie, O. \& Tourish, D. (2009) Auditing organizational communication. London: Routledge.

Harter, J. K., Schmidt, F. L., \& Hayes, T. L. (2002) Business-unit level relationship between employee satisfaction, employee engagement, and business outcomes: a meta- analysis. Journal of Applied Psychology, 87(2), 268-79.

Hewitt Associates LLC (2004) Research brief: Employee engagement higher at double-digit growth companies. Retrieved from www.hewitt.com $10^{\text {th }}$ March 2010.

Hirschman, A. O. (1970) Exit, voice and loyalty: Responses to decline in firms, organizations, and states. Cambridge, Mass.: Harvard University Press.

Illes, K., \& Mathews, M. (2015) Leadership Trust and Communication: Building Trust in Companies Through Effective Leadership Communication. Westminster Business School, University of Westminster, in collaboration with Top Banana and the Institute of Internal Communication.

Johansson, C., Miller, V.D., \& Hamrin, S. (2014) Conceptualizing communicative leadership. Corporate Communications: An International Journal. 19(2), pp.147 - 165.

Kahn, W. A. (1990) Psychological conditions of personal engagement and disengagement at work. Academy of Management Journal, 33(4), 692-724.

Kahn, W. A. (1992) To be fully there: Psychological presence at work. Human Relations 45(4), 321-349.

Kahn, W. A. (2010) The essence of engagement. In Albrecht, S. L (Ed) (2010) Handbook of employee engagement: Perspectives, issues, research and practice. Cheltenham: Edward Elgar.

Kassing, J. W. (1998) Development and validation of the organizational dissent scale. Management Communication Quarterly, 12(2), 183-229.

Kaufman, B. T. (2014) Employee voice before Hirschman: its early history, conceptualization, and practice. In Wilkinson, A., Donaghey, J., Dundon, T., \& Freeman, R.B. (2014). Handbook of Research on Employee Voice (pp. 17-35). Cheltenham: Edward Elgar.

Kent, M.L., \& Taylor, M. (2002) Toward a dialogic theory of public relations. Public Relations Review, 28(1), pp.21-37.

Little, B., \& Little, P. (2006) Employee engagement: conceptual issues. Journal of Organizational Culture, Communications and conflict, 10(1), 111-120.

Luthans, F., \& Peterson, S. J. (2002) Employee engagement and manager self-efficacy: implications for managerial effectiveness and development. Journal of Management Development, 21(5), 376-387. 
Marchington, M. (2015) Analysing the forces shaping employee involvement and participation (EIP) at organisation level in liberal market economies (LMEs). Human Resource Management Journal, 25(1), 118.

Maslach, C., Schaufelli, W.B. \& Leiter, M.P. (2001) Job burnout. Annual Review of Psychology Quarterly, 52(1), 397-422.

May, D. R., Gilson, R. L., \& Harter, L. M. (2004) The psychological conditions of meaningfulness, safety and availability and the engagement of the human spirit at work. Journal of Occupational and Organizational Psychology Quarterly, 77(1), 11-37.

Men, L.R. (2014) Why Leadership Matters to Internal Communication: Linking Transformational Leadership, Symmetrical Communication, and Employee Outcomes. Journal of Public Relations Research. 26(3), pp.256-279.

Neill, S. M. (2015) Emerging Issues in Internal Communications: Generational Shifts, Internal Social Media \& Engagement. Public Relations Journal, 9(4), 1-20.

Nilsson, T. (2010) The reluctant rhetorician: senior managers as rhetoricians in a strategic change context. Journal of Organizational Change Management. 23(2), pp.137-144.

Purcell, J. (2014) Employee voice and engagement. In Truss, C., Delbridge, R., Alfes, K., Shantz, A., \& Soane, E. (Eds). Employee Engagement in Theory and Practice. Abingdon: Routledge

Purcell, J., Kinnie, N., Hutchinson, S., Rayton, B., \& Swart, J. (2003) Understanding the People and Performance Link: Unlocking the Black Box. London, CIPD.

Purcell, J., \& Hall, M. (2012) Voice and participation in the modern workplace: Challenges and prospects. Future of Workplace Relations Discussion Paper Series. London: Acas.

Quinn, D., \& Hargie, O. (2004) Internal communication audits: a case study. Corporate Communications: An International Journal, 9(2), 146-158.

Rees, C., Alfes, A., \& Gatenby, M. (2013) Employee voice and engagement: connections and consequences. The International Journal of Human Resource Management, 24(14), 2780-2798.

Reissner, S., \& Pagan, P. (2013) Generating employee engagement in a public-private partnership: management communication activities and employee experiences. The International Journal of Human Resource Management, 24(14), 2741-2759.

Roberts, K. H., \& O'Reilly, C. A. (1974) Failures in upward communication in organizations: Three possible culprits. Academy of Management Journal Quarterly, 17(2), 205-215.

Robinson, D., Perryman, S., \& Hayday, S. (2004) The Drivers of Employee Engagement. Brighton: Institute for Employment Studies.

Robson, P. J., \& Tourish, D. (2005) Managing internal communication: an organizational case study. Corporate Communications: An International Journal, 10(3), 213-222.

Rothmann, S. (2014) Employee engagement in a cultural context. In Truss, C., Alfes, K., Delbridge, R., Shantz, A., \& Soane, E. (2014) Employee engagement in theory and practice pp. 163-179. Abingdon: Routledge.

Ruck, K., \& Welch, M. (2012) Valuing internal communication; management and employee perspectives. Public Relations Review, 38(2), 294-302. 
Saks, A. M. (2006) Antecedents and consequences of employee engagement. Journal of Managerial Psychology, 21(7), 600-619.

Schaufeli, W. B. (2014) What is engagement? In Truss, C., Alfes, K., Delbridge, R., Shantz, A., \& Soane, E. (2014). Employee engagement in theory and practice pp. 15-35. Abingdon: Routledge.

Schaufeli, W. B., \& Bakker, A. B. (2004) Job demands, job resources, and their relationship with burnout and engagement: a multi-sample study. Journal of Organizational Behavior Quarterly, 25(3), 293-315.

Schaufeli, W. B., \& Bakker, A. B. (2010) Defining and measuring work engagement: Bringing clarity to the concept. In Bakker, A. B., Leiter, M. P. (Eds) (2010) Work engagement: A handbook of essential theory and research. Hove: Psychology Press.

Seltzer, T., Gardner, E., Bichard, S., \& Callison, C. (2012) PR in the ER: Managing internal organization-public relationships in a hospital emergency department. Public Relations Review, 38(1), 128-136.

Shuck, B., \& Wollard, K. (2010) Employee engagement and HED: A seminal review of the foundations. Human Resource Development Journal Quarterly, 9(1), 89-110.

Taylor, M. \& Kent, M.L. (2014) Dialogic engagement: Clarifying foundational concepts. Journal of Public Relations Research, 26(5), pp.384-398.

Theunissen, P. \& Noordin, W.N.W. (2012) Revisiting the concept "dialogue" in public relations. Public Relations Review, 38(1), pp.5-13.

Tourish, D. (2013) The Dark Side of Transformational Leadership, A Critical Perspective. Hove: Routledge.

Tourish, D., \& Robson, P. (2006) Sensemaking and the distortion of critical upward communication in organizations, Journal of Management Studies, 43(4), 711-730.

Tourish, D., \& Robson, P. (2003) Critical upward feedback in organizations: processes, problems and implications for communication management. Journal of Communication Management, 8(2), 150-167.

Truss, C., Soane, E., Edwards, C., Wisdom, K., Croll, A., \& Burnett, J. (2006) Working life: employee attitudes and engagement 2006. London: Chartered Institute of Personnel Development.

Van Dyne, L., Ang, S., \& Botero, I.C. (2003) Conceptualizing Employee Silence and Employee Voice as Multidimensional Constructs. Journal of Management Studies. 40(6), 1359-1392.

Van Wenrooy, B., Bewley, H., Bryson, A., Forth, J., Freeth, S., Stokes, \& L., Wood, S. (2013) The 2011 Workplace Employment Relations Study, First Findings. Department for Business, Innovation \& Skills. Retrieved from: https://www.gov.uk/government/publications/the-2011-workplace-employment-relationsstudy-wers, 23rd January 2013.

Verčič, A. T., Verčič, D., \& Sriramesh, K. (2012) Internal communication: Definition, parameters, and the future. Public Relations Review, 38(2), 223-230.

Walker, R., \& Aritz, J. (2014) Leadership Talk, A Discourse Approach to Leader Emergence. New York: Business Expert Press.

Welch, M. (2011) The evolution of the employee engagement concept: communication implications. Corporate Communications: An International Journal, 16(4), 328-346.

Welch, M., \& Jackson, P. R. (2007) Rethinking internal communication: a stakeholder approach. Corporate Communications: An International Journal Quarterly, 12(2), 177-198. 
Wilkinson, A., Dundon, T., Marchington, M., \& Ackers, P. (2004) Changing Patterns of Employee Voice: Case Studies From the UK and the Republic Of Ireland. Journal of Industrial Relations, 46(3), 298-322.

Wilkinson, A., Donaghey, J., Dundon, T., \& Freeman, R.B. (2014) Handbook of Research on Employee Voice. Cheltenham: Edward Elgar.

Workplace Employment Relations Survey (WERS) (2011) Retrieved from http://www.wers2011.info/ $13^{\text {th }}$ June 2016.

Zwijze-Koning, K. H., \& de Jong, M. D. T. (2007) Evaluating the communication satisfaction questionnaire as a communication audit tool. Management Communication Quarterly, 10(3), 261-282. 